\title{
Fuzzy Evaluation of Low Carbon Development Levels for Logistic Enterprises in China
}

\author{
Peixin Zhao*, Haoran Yu, Zhiyang Wang, Lulu Xu \\ School of Management, Shandong University (China) \\ *Corresponding author:pxzhao@126.com, edward hr@,163.com, kingdreamsun@sina.com, xulu2199@,126.com
}

Received: August 2015

Accepted: December 2015

\section{Abstract:}

Purpose: Under the background of global warming, low carbon economy, which is based on low waste and low pollution, has become a globally focused topic. Energy conservation, emission reduction and low carbon development have become irresistible trends of social development. A new set of low carbon evaluation index system for logistics enterprises is proposed. It is helpful for the better monitor of low carbon production and provide the optimization of industrial policies in China.

Design/methodology/approach: Based on the problem that logistic analyses are facing under the background of low carbon economy, this paper firstly establishes a set of new evaluation indexes system, including 5 first-level indices and 28 second-level indices, for the low carbon development levels of logistics enterprises in China. To simplify the new evaluation system, the weight judgment method is then used to select indices, the validity judgment method and reliability coefficient judgment method are respectively used to test the validity and reliability of the evaluation systems. The simplified evaluation system consists of 4 first-class indices and 20 second-class indexes. Finally, numerical examples illustrate the validity and operability of the evaluation system.

Findings: From the analysis and evaluation results, it is not difficult to obtain the rank of logistics enterprise according to the selected indexes or the overall evaluation indices. Low scores of some key indexes in strategy indices and technical indices cause low carbon emission 
performance. Moreover, The reason for the good low carbon performance of one enterprises is that it is in the lead on the key indexes of high weighs such as Perfection degree of low carbon development strategy, Level of transportation route optimization, etc. The new evaluation index system also helps enterprises to realize the sustainable development by identifying the key factors that affect the low carbon development level.

Originality/value: The existing literature that assesses low carbon logistics is mostly focused on the review of the location-based and industry-based aspects, and little attention has been paid to assessing the efficiency of low carbon logistics from the components that are within the logistics enterprises. Therefore, we develop a new low carbon evaluation index system for logistics enterprises in order to better monitor low carbon production and provide the optimization of industrial policies in China.

Keywords: clustering analysis, evaluation system, fuzzy evaluation, logistics, low carbon

\section{Introduction}

Under the background of global warming, low carbon economy, which is based on low waste and low pollution, has become a globally focused topic. Energy conservation, emission reduction and low carbon development have become irresistible trends of social development. Low carbon development requires reducing greenhouse gas generated by production and people's livelihood in order to prevent environment from deteriorating and to achieve sustainable development. Since Britain firstly proposed the concept of low carbon economics, energy conservation and sustainable development have attracted the world's attention, every country comes to realize that low carbon economics is an irresistible trend (Geng \& He, 2011; Phillips \& Dickie, 2014; Shen et al., 2014).

As the climate problem worsens, global low carbon revolution is springing up. People are stepping into a new low carbon century, which is based on "low energy consumption, low pollution and low emission". Low carbon logistics aims to restrain the harm logistics process gives to environment via scientific management methods, help us sufficiently utilize resources, apply the concept of environment protection to every system of logistics industry, improve the management and supervision of transportation, packaging, loading and unloading, storage and recycling parts of logistics, and efficiently restrain the waste and pollution that logistics processes caused (Ren \& Wu, 2011). As one of the ten major industries in China, logistics holds a special position in the low carbon economic development. Since the logistics industry of China is of low level of socialization and professionalization, economic development always leads to a higher cost - the overall social logistics cost occupies nearly 20 percent of the GDP. 
However, in the United States and Japan, it is less than 10 percent, and the average is about 16 percent in other moderately developed countries. The extensive and low-efficient logistic operation model causes increases in energy consumption and energy waste. Therefore, it is very important to evaluate the low carbon development level of logistics enterprises for green logistics management. Low carbon level evaluation may orient and improve the low carbon logistics.

\section{Literature Review}

The current low-carbon evaluation systems are mainly focused on the studies of the lowcarbon economy. For example, Tsai and Chang (2015) utilized the MARKAL energy engineering model to simulate the effects of adopting a combination of technology and tax measures under the various carbon reduction targets and low-carbon development scenarios up to 2050 in Taiwan. Bi, Huang and Ye (2015) analyzes the risk of low-carbon technological innovation in emerging economies under globalization, by integrating the method of global value chain (GVC) and technological innovation linear progress into a new analytical framework. Zhuang, Pan and Zhu (2011) presented a measure index system, including low-carbon output, lowcarbon consumption, low-carbon resources and low-carbon policy, then made further suggestions for improvement to meet practical requirement. Li and Deng (2010) proposed a comprehensive evaluation index system of the city's low-carbon economy, including economic systems, technological systems, social systems and environmental systems 4-level indicators and 27-secondary indicators, and conducted empirical researches. Zhao, Sun and Liu (2009) designed an evaluation indicator system through doing an overview of sustainable development indicators home and abroad.

For the past few years, researches in low carbon logistics enterprises have become more in depth than before: Wu (2011) constructed an evaluation system for the third party reverse logistics enterprises in electronics industry's selection from five perspectives; Wang (2012) proposed that logistics enterprises should define restrain conditions of low carbon economy and adjust the adaptive development strategies. This proposal can be referenced to when it comes the evaluation of logistics enterprises; Li, Xiong and Zhang (2011) constructed an evaluation system of the key factors that affect the development of enterprises' low carbon logistics with respect of government, enterprises and industries; Fan (2014) built a suite of evaluation index systems to measure low carbon logistics impact on the environment, including enterprises operating, resource and energy utilization and environmental impacts. The existing literature that assesses low carbon logistics is mostly focused on the review of the locationbased and industry-based aspects, and little attention has been paid to assessing the efficiency of low carbon logistics from the components that are within the logistics enterprises. Therefore, we will develop a new low carbon evaluation index system for logistics enterprises 
in order to better monitor low carbon production in China and provide optimal industrial policies.

Building upon the previous studies, this paper firstly constructs a set of evaluation system including 5 first-level indies and 28-second level indices to evaluate the low carbon level of logistics enterprises, and uses weight judgment method, validity judgment method and reliability coefficient method to filtrate and select the indexes. Finally we obtain a set of fuzzy comprehensive evaluation system including 4 first level indices and 20 second level indices for low carbon logistics performance evaluation. The numerical example indicates the validity and operability of this evaluation system.

\section{Construction of Evaluation Index System}

\subsection{The Principle and Design of Evaluation Index System}

There are many kinds of evaluation indexes for the low carbon logistics, such as quantitative indexes and qualitative indexes. In order to reasonably and scientifically evaluate the level of low carbon logistics, a scientific, multi-dimensional evaluation index system should be constructed according to the following principles (Feng, 2011; Hu \& Ding, 2010; Luo \& Xiao, 2011; Wu, 2011):

- The evaluation system should be able to be used to reflect the current situation and the future development trend of logistics enterprise comprehensively and objectively;

- The index should be layered, such that the overall evaluation system can be kept coordinated longitudinally, horizontally and internally;

- Flexibility;

- Practicability. The evaluation system should be able to scientifically reflect the characteristics and the real situation of enterprises; it should not be redundant or oversimplified;

- The index should be relatively stable in a certain period of time. The low carbon development of logistics enterprises is a dynamic process. Therefore, the design of index should have the feature of dynamics so as to reflect the dynamic development process of logistics enterprises.

- The combination of quantitative and qualitative indexes. The index evaluation system should be comparable and testable.

Based on the above principles, the index evaluation system that affects the factor of the development of low carbon logistics in China is constructed. First, we macroscopically determine three crucial factors, which affect logistics enterprises' low carbon development, as 
the first-class indexes, namely strategy indexes, technology indexes and process indexes. Strategy indexes are mainly used to reflect the strategies enterprises adopt to develop low carbon logistics, including the degree of response to the national policies, the goal and detailed measures of low carbon development. Low carbon logistics technology indexes are mainly used to reflect the core factors of the low carbon logistics technologies, which can be classified to hard technology and soft technology. Hard technology can be measured in terms of the investment on hardware facilities, the amount of purchased facilities, and the utility efficiency of hardware facilities. Soft technology is mainly reflected in the exploitation and import of low carbon technologies and the informatization level of enterprises. The technological innovative ability depends on the manpower, material resources and financial resources. The investment in low carbon technology research and the scientific manpower are the foundation and important support for technological innovation, respectively (Feng, 2010). The level of informatization is reflected in the proportion of investment for informatization development ( $\mathrm{Ni}$ $\& \mathrm{Xu}, 2007)$, the construction of information system and network information platform, the comprehensive equipment rate and utility rate of information system (Xiao, Yin, Wang \& Shi, 2005), the popularizing rate of enterprises information skills and the general informatization level of employee. Low carbon logistics process indices are used to analyze the different kinds of factors in various parts that affect the low carbon logistics (Wu, 2011; Ding, 2011), and can be generalized into forward and reverse indices. Forward indices mainly include low carbon transportation, low carbon storage, low carbon loading and unloading, low carbon transportation, low carbon packaging, and low carbon distribution; reverse indices mainly include low carbon waste disposal and low carbon reprocessing and recycling.)

After the preliminary selection of above indices, we construct the low carbon development evaluation index system for logistics enterprise in China as showed in the first and second column of Table $1, x_{i j}$ represents the index value of the $j$ th second-class index in the $i$ th firstclass index.

\begin{tabular}{|c|c|c|c|c|c|c|c|c|c|}
\hline \multirow{2}{*}{$\begin{array}{l}\text { First level } \\
\text { indices }\end{array}$} & \multirow{2}{*}{$\begin{array}{l}\text { Second level } \\
\text { indices }\end{array}$} & \multicolumn{4}{|c|}{$\begin{array}{l}\text { Logistics } \\
\text { Enterprises }\end{array}$} & \multirow{2}{*}{$\begin{array}{c}\text { Index } \\
\text { code }\end{array}$} & \multirow{2}{*}{$\begin{array}{l}\text { Factor } \\
\text { loading }\end{array}$} & \multirow{2}{*}{$\begin{array}{c}\text { Factor } \\
\text { Contribution } \\
\text { rate }\end{array}$} & \multirow{2}{*}{$\begin{array}{l}\text { Index } \\
\text { selected }\end{array}$} \\
\hline & & & $1 \mathrm{E}$ & $E_{3}$ & & & & & \\
\hline \multirow{5}{*}{$\begin{array}{l}\text { Strategy } \\
\text { indexes }\end{array}$} & $\begin{array}{l}\text { Response degree of } \\
\text { national low carbon } \\
\text { policy }\end{array}$ & 8.5 & 7.3 & 6.5 & 7.5 & $x_{1,1}$ & - & 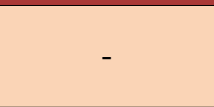 & $x_{1,1}$ \\
\hline & $\begin{array}{l}\text { Perfection degree of } \\
\text { low carbon } \\
\text { development strategy }\end{array}$ & 8.0 & 7.1 & 7.0 & 7.9 & $x_{1,2}$ & 0.991 & \multirow{4}{*}{$95.80 \%$} & \multirow{4}{*}{$x_{1,2}$} \\
\hline & $\begin{array}{l}\text { low carbon } \\
\text { development target } \\
\text { setting }\end{array}$ & 8.8 & 8.0 & 7.8 & 8.6 & $x_{1,3}$ & 0.965 & & \\
\hline & $\begin{array}{l}\text { Determination of low } \\
\text { carbon development } \\
\text { mode }\end{array}$ & 8.3 & 7.5 & 7.6 & 8.5 & $x_{1,4}$ & 0.987 & & \\
\hline & $\begin{array}{l}\text { Implementation of } \\
\text { low carbon } \\
\text { development } \\
\text { measures }\end{array}$ & 6.7 & 6.0 & 6.1 & 7.0 & $x_{1,5}$ & 0.971 & & \\
\hline
\end{tabular}




\begin{tabular}{|c|c|c|c|c|c|c|c|c|c|}
\hline $\begin{array}{l}\text { First level } \\
\text { indices }\end{array}$ & $\begin{array}{l}\text { Second level } \\
\text { indices }\end{array}$ & & $\begin{array}{r}\text { Log } \\
\text { Ente }\end{array}$ & $\begin{array}{l}\text { istics } \\
\text { rprise }\end{array}$ & & $\begin{array}{l}\text { Index } \\
\text { code }\end{array}$ & $\begin{array}{l}\text { Factor } \\
\text { loading }\end{array}$ & $\begin{array}{c}\text { Factor } \\
\text { Contribution } \\
\text { rate }\end{array}$ & $\begin{array}{l}\text { Index } \\
\text { selected }\end{array}$ \\
\hline \multirow{18}{*}{$\begin{array}{l}\text { Technology } \\
\text { indexes }\end{array}$} & $\begin{array}{l}\text { The proportion of } \\
\text { purchase cost for } \\
\text { hardware facilities }\end{array}$ & 8.6 & 7.0 & 8.0 & 9.0 & $x_{2,1}$ & 0.998 & \multirow[t]{2}{*}{$99.60 \%$} & \multirow{2}{*}{$x_{2,2}$} \\
\hline & $\begin{array}{l}\text { The number of } \\
\text { hardware facilities }\end{array}$ & 8.3 & 7.6 & 8.2 & 8.6 & $x_{2,2}$ & 0.998 & & \\
\hline & $\begin{array}{l}\text { Utilization rate of } \\
\text { hardware facilities }\end{array}$ & 7.5 & 6.7 & 8.7 & 7.9 & $x_{2,3}$ & - & - & $x_{2,3}$ \\
\hline & $\begin{array}{l}\text { The introduction of } \\
\text { low carbon } \\
\text { technologies }\end{array}$ & 5.8 & 6.0 & 5.0 & 5.2 & $x_{2,4}$ & - & - & $x_{2,4}$ \\
\hline & $\begin{array}{l}\text { Proportion of } \\
\text { investment for low } \\
\text { carbon research }\end{array}$ & 6.0 & 5.6 & 5.0 & 5.7 & $x_{2,5}$ & - & - & $x_{2,5}$ \\
\hline & $\begin{array}{l}\text { Technological } \\
\text { innovation capability }\end{array}$ & 5.7 & 5.2 & 5.0 & 4.8 & $x_{2,6}$ & 0.998 & \multirow{4}{*}{$98.14 \%$} & \multirow{4}{*}{$x_{2,6}$} \\
\hline & $\begin{array}{l}\text { Proportion of } \\
\text { Scientific research } \\
\text { personnel }\end{array}$ & 6.5 & 5.7 & 5.5 & 5.6 & $x_{2,7}$ & 0.988 & & \\
\hline & $\begin{array}{l}\text { Number of low carbon } \\
\text { research project }\end{array}$ & 5.5 & 4.8 & 4.6 & 4.5 & $x_{2,8}$ & 0.983 & & \\
\hline & $\begin{array}{l}\text { Research } \\
\text { achievements in low } \\
\text { carbon technology } \\
\text { research }\end{array}$ & 6.3 & 4.9 & 4.3 & 4.5 & $x_{2,9}$ & 0.993 & & \\
\hline & $\begin{array}{l}\text { Technical equipment } \\
\text { rate of information } \\
\text { system }\end{array}$ & 8.4 & 7.7 & 7.5 & 8.5 & $X_{2,10}$ & 0.99 & \multirow{4}{*}{$96.05 \%$} & \multirow{4}{*}{$x_{2,10}$} \\
\hline & $\begin{array}{l}\text { Proportion of } \\
\text { investment for } \\
\text { informatization }\end{array}$ & 8.2 & 7.2 & 7.3 & 8.1 & $x_{2,11}$ & 0.977 & & \\
\hline & $\begin{array}{l}\text { The construction of } \\
\text { logistics information } \\
\text { system }\end{array}$ & 8.3 & 7.5 & 7.7 & 8.5 & $x_{2,12}$ & 0.979 & & \\
\hline & $\begin{array}{l}\text { The construction of } \\
\text { network information } \\
\text { platform }\end{array}$ & 8.4 & 7.9 & 7.7 & 8.7 & $x_{2,13}$ & 0.975 & & \\
\hline & $\begin{array}{l}\text { Utilization rate of } \\
\text { Information system }\end{array}$ & 8.5 & 7.5 & 8.4 & 7.8 & $x_{2,14}$ & - & - & $x_{2,14}$ \\
\hline & $\begin{array}{l}\text { Informatization level } \\
\text { of employee }\end{array}$ & 8.3 & 7.4 & 7.3 & 7.8 & $X_{2,15}$ & 0.996 & \multirow{4}{*}{$96.90 \%$} & \multirow{4}{*}{$x_{2,15}$} \\
\hline & $\begin{array}{l}\text { Performance of the } \\
\text { information systems }\end{array}$ & 7.5 & 7.0 & 7.1 & 7.3 & $x_{2,16}$ & 0.98 & & \\
\hline & $\begin{array}{l}\text { The proportion of } \\
\text { information } \\
\text { technology personnel }\end{array}$ & 7.0 & 6.0 & 6.1 & 6.6 & $x_{2,17}$ & 0.992 & & \\
\hline & $\begin{array}{l}\text { Popularization rate of } \\
\text { Information skills }\end{array}$ & 7.0 & 6.6 & 6.5 & 6.9 & $X_{2,18}$ & 0.97 & & \\
\hline
\end{tabular}




\begin{tabular}{|c|c|c|c|c|c|c|c|c|c|}
\hline $\begin{array}{l}\text { First level } \\
\text { indices }\end{array}$ & $\begin{array}{l}\text { Second level } \\
\text { indices }\end{array}$ & \multicolumn{4}{|c|}{$\begin{array}{l}\text { Logistics } \\
\text { Enterprises }\end{array}$} & $\begin{array}{l}\text { Index } \\
\text { code }\end{array}$ & $\begin{array}{l}\text { Factor } \\
\text { loading }\end{array}$ & $\begin{array}{l}\text { Factor } \\
\text { Contribution } \\
\text { rate }\end{array}$ & $\begin{array}{l}\text { Index } \\
\text { selected }\end{array}$ \\
\hline \multirow{25}{*}{ Process indexes } & $\begin{array}{l}\text { Level of } \\
\text { transportation route } \\
\text { optimization }\end{array}$ & 7.0 & 7.1 & 6.3 & 6.1 & $x_{3,1}$ & 0.984 & \multirow{5}{*}{$94.01 \%$} & \multirow{5}{*}{$x_{3,1}$} \\
\hline & $\begin{array}{l}\text { Proportion of low } \\
\text { carbon transportation } \\
\text { vehicles }\end{array}$ & 8.0 & 7.7 & 6.5 & 6.8 & $x_{3,2}$ & 0.968 & & \\
\hline & $\begin{array}{l}\text { Proportion of clean } \\
\text { energy }\end{array}$ & 7.4 & 7.3 & 6.7 & 6.4 & $x_{3,3}$ & 0.979 & & \\
\hline & Empty loaded rate & 3.4 & 3.2 & 4.2 & 4.0 & $x_{3,4}$ & 0.948 & & \\
\hline & $\begin{array}{l}\text { Repeated } \\
\text { transportation }\end{array}$ & 2.0 & 2.3 & 2.8 & 3.0 & $x_{3,5}$ & 0.969 & & \\
\hline & $\begin{array}{l}\text { Low carbon level of } \\
\text { storage }\end{array}$ & 7.9 & 7.0 & 7.3 & 8.5 & $x_{3,6}$ & 0.995 & & \\
\hline & Inventory carry rate & 7.5 & 6.9 & 7.2 & 7.9 & $x_{3,7}$ & 0.978 & & \\
\hline & $\begin{array}{l}\text { Utilization rate of } \\
\text { warehouse }\end{array}$ & 7.7 & 6.9 & 7.0 & 8.0 & $x_{3,8}$ & 0.978 & $96.19 \%$ & $x_{3}$ \\
\hline & $\begin{array}{l}\text { Proportion of Low } \\
\text { energy consumed } \\
\text { equipments }\end{array}$ & 7.0 & 6.5 & 6.7 & 7.5 & $x_{3,9}$ & 0.988 & & 3,6 \\
\hline & $\begin{array}{l}\text { Utilization of green } \\
\text { structural material }\end{array}$ & 7.4 & 7.0 & 6.8 & 7.8 & $x_{3,10}$ & 0.965 & & \\
\hline & $\begin{array}{l}\text { Low carbon level of } \\
\text { processing }\end{array}$ & 7.7 & 8.5 & 8.6 & 7.6 & $x_{3,11}$ & 0.989 & & \\
\hline & $\begin{array}{l}\text { Specification of } \\
\text { operational approach }\end{array}$ & 7.5 & 8.2 & 7.9 & 7.2 & $x_{3,12}$ & 0.939 & & \\
\hline & $\begin{array}{l}\text { Standardization of } \\
\text { operation }\end{array}$ & 6.8 & 8.0 & 8.3 & 7.1 & $x_{3,13}$ & 0.955 & & \\
\hline & $\begin{array}{l}\text { Proportion of low- } \\
\text { energy processing } \\
\text { equipments }\end{array}$ & 6.6 & 7.6 & 7.5 & 6.9 & $x_{314}$ & 0.961 & $93.19 \%$ & $X_{3,11}$ \\
\hline & $\begin{array}{l}\text { Centralized utilization } \\
\text { rate of process } \\
\text { facilities }\end{array}$ & 7.5 & 8.3 & 8.1 & 7.3 & $x_{3,15}$ & 0.982 & & \\
\hline & $\begin{array}{l}\text { Low carbon level of } \\
\text { loading and handling }\end{array}$ & 8.0 & 7.4 & 8.3 & 8.4 & $x_{3,16}$ & 0.993 & & \\
\hline & Distribution error rate & 2.1 & 2.6 & 1.7 & 1.6 & $x_{3,17}$ & 0.986 & & \\
\hline & Damage rate of goods & 1.7 & 2.0 & 1.5 & 1.6 & $x_{3,18}$ & 0.986 & $97.92 \%$ & $x_{3,16}$ \\
\hline & $\begin{array}{l}\text { Repeated handling } \\
\text { rate }\end{array}$ & 2.1 & 2.8 & 1.8 & 1.9 & $x_{3,19}$ & 0.993 & & \\
\hline & $\begin{array}{l}\text { Low carbon level of } \\
\text { packaging }\end{array}$ & 7.6 & 6.4 & 6.1 & 7.0 & $x_{3,20}$ & 0.998 & & \\
\hline & $\begin{array}{l}\text { Proportion of low } \\
\text { carbon packaging } \\
\text { material }\end{array}$ & 7.8 & 5.8 & 6.0 & 6.8 & $x_{3,21}$ & 0.973 & $97.07 \%$ & $x_{3,20}$ \\
\hline & $\begin{array}{l}\text { Cyclic utilization rate } \\
\text { of packaging material }\end{array}$ & 7.3 & 6.6 & 6.3 & 7.0 & $x_{3,22}$ & 0.984 & & \\
\hline & $\begin{array}{l}\text { Comprehensive } \\
\text { utilization rate of } \\
\text { waste }\end{array}$ & 6.3 & 7.2 & 6.0 & 5.7 & $x_{3,23}$ & 0.996 & & \\
\hline & $\begin{array}{l}\text { Recovery rate of } \\
\text { waste }\end{array}$ & 6.5 & 7.2 & 6.2 & 6.4 & $x_{3,24}$ & 0.952 & $95.14 \%$ & $x_{3,23}$ \\
\hline & $\begin{array}{l}\text { Success rate of waste } \\
\text { disposal }\end{array}$ & 6.3 & 7.3 & 5.9 & 5.3 & $x_{3,25}$ & 0.977 & & \\
\hline
\end{tabular}

Table 1. Low carbon evaluation index system and results of clustering-factor analysis

\subsection{The Quantification and Standardization of Index Data}

There are many qualitative indices in the evaluation system, which need to be quantified before evaluation. There are some common quantitative approaches to deal with qualitative index, such as normal distribution methods, binary comparison methods, and expert investigation scoring methods (Xu \& Bao, 2011). Expert investigation scoring method is wildly 
used because it can be operated easily and fully utilizes experts' knowledge. Meanwhile, index data should be standardized in order to make different kinds of index comparable (Gu, Chi \& Cheng, 2010): Suppose that there are $m$ enterprises to be evaluated, and there are $g$ firstclass indices and $n$ second-class indices. $x_{i, j}^{d}$ represents the score of the $d$ th enterprise with respect to the $j$ th second-class index in the first-class index, $r_{i, j}^{d}$ represents the standardized score of the $d$ th enterprise with respect to the $j$ th second-class index in the $i$ th first-class index. A larger forward index score indicates a higher low carbon level, and the standardized formula are (Eq. 1):

$$
r_{i, j}^{d}=\frac{x_{i, j}^{d}-\min _{1 \leq i \leq m}\left\{x_{i, j}^{d}\right\}}{\max _{1 \leq i \leq m}\left\{x_{i, j}^{d}\right\}-\min _{1 \leq i \leq m}\left\{x_{i, j}^{d}\right\}}
$$

or (Eq. 2):

$$
r_{i, j}^{d}=\frac{\max _{1 \leq i \leq m}\left\{x_{i, j}^{d}\right\}-x_{i, j}^{d}}{\max _{1 \leq i \leq m}\left\{x_{i, j}^{d}\right\}-\min _{1 \leq i \leq m}\left\{x_{i, j}^{d}\right\}}
$$

\subsection{Index Selection}

We synthetically analyze all factors that may influence enterprise low carbon development and try to get a set of comprehensive and effective evaluation indices. Since too many evaluation indices may lead to index that weights dispersing and distortion of the evaluation results, we should delete indices that are essentially the same or similar according to the following methods:

First, we classify the cases and variables by using $Q$ and $R$ cluster analysis, then for each firstlevel index, cluster the secondary indices that belong to it by using Ward method. Finally, we can use the factor analysis method to select the most significant indices that contain maximum amount of information in each category (He, 2007).

This paper illustrates the selection process by evaluating the low carbon development level of four practical companies. E1, E2, E3, and E4 represent four companies. By using the Delphi method, scores of each index are showed in Table 1. SPSS17.0 is used to cluster the secondary indexes and $\mathrm{K}-\mathrm{W}$ nonparametric test is used to determine the reasonable number of clusters. Figure 1 shows the cluster results of process indices (clustering results of strategic indices and technology indices are omitted. The final evaluation index system is showed in column 7, Table 1. 


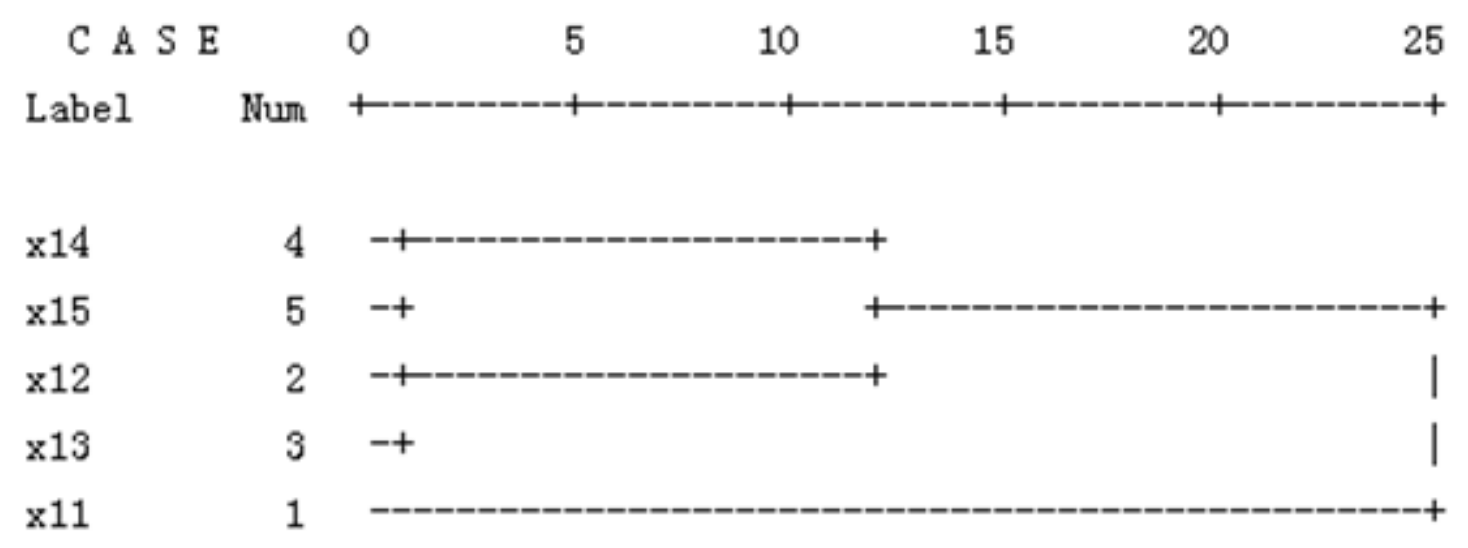

Figure 1. Clustering results of strategy indexes

\section{Fuzzy Evaluation of Low Carbon Development Levels}

Through the filtering of indexes shown from above, a simplified and typical evaluation system of the low carbon development level for logistics enterprises can be obtained (see Table 1). Considering that some indices will become more extensively and profoundly representative after cluster analysis, a fuzzy evaluation result by experts is allowed, so the fuzzy evaluation method can be used to analyze the final low carbon development level of enterprises. The process can be summarized as follows:

Step 1. Determine the evaluation index set of low carbon development level of enterprises. $E_{i}(i=1,2, \ldots, m)$ represents the $i$ th logistics enterprises to be evaluated, and there are $g$ firstlevel indices $\left(T_{1}, T_{2}, \ldots, T_{g}\right)$ and $n$ second-level indices in the index set $T$. The weight of the firstlevel indices is $\left(\varpi_{1}, \varpi_{2}, \ldots, \varpi_{g}\right)$. As for the second-level indices $T_{d}$, its weight is $\varpi_{d j}\left(j=1,2, \ldots p_{d}\right)$.

Step 2. Determine the membership degree. $x_{i, j}^{d}$ represents the characteristic value of the $j^{\text {th }}$ second level index in the $i^{\text {th }}$ first level index of the $d^{\text {th }}$ enterprise, $X_{i}=\left(x_{i, j}^{d}\right)_{p_{d} \times m}$ the target characteristic value matrix for the $i^{\text {th }}$ first level index. Through data standardization equation, the target characteristic value matrix can be transformed into target relative superiority matrix $R_{i}=\left(r_{i, j}^{d}\right)_{p_{d} \times m}$.

Step 3. The second level fuzzy comprehensive evaluation of $T_{d}(d=1,2, \ldots, g)$. Let $h_{d j}=\max _{i}\left\{r_{i, j}^{d}\right\}, b_{d j}=\min _{i}\left\{r_{i, j}^{d}\right\}$, then $h_{d}=\left(h_{d 1}, h_{d 2}, \ldots, h_{d p_{d}}\right)$ and $b_{d}=\left(b_{d 1}, b_{d 2}, \ldots, b_{d p_{d}}\right)$ can be respectively named as, for $T_{d}$, the superior relative superiority vector and the inferior relative superiority vector. According to principle of least squares, the membership vector for each enterprise can be obtained: $U_{d}=\left(u_{1}^{d}, u_{2}^{d}, \ldots, u_{m}^{d}\right), d=1,2, \ldots, g$ 


\begin{tabular}{|c|c|c|c|c|c|c|c|}
\hline \multicolumn{2}{|c|}{ First level indices } & Second level indices & \multicolumn{5}{|c|}{ Low carbon logistic enterprises } \\
\hline Designation & Weight & Designation & Weight & $E_{1}$ & $E_{2}$ & $E_{3}$ & $E_{4}$ \\
\hline \multirow{2}{*}{ Policy indexes } & \multirow{2}{*}{0.20} & $\mathrm{X}_{1,1}$ & 0.40 & 8.5 & 7.3 & 6.5 & 7.5 \\
\hline & & $x_{1,2}$ & 0.60 & 8.0 & 7.1 & 7.0 & 7.9 \\
\hline \multirow{8}{*}{$\begin{array}{l}\text { Technical } \\
\text { indexes }\end{array}$} & \multirow{8}{*}{0.45} & $x_{2,2}$ & 0.10 & 8.3 & 7.6 & 8.2 & 8.6 \\
\hline & & $x_{2,3}$ & 0.15 & 7.5 & 6.7 & 8.7 & 7.9 \\
\hline & & $x_{2,4}$ & 0.10 & 5.8 & 6.0 & 5.0 & 5.2 \\
\hline & & $x_{2,5}$ & 0.15 & 6.0 & 5.6 & 5.0 & 5.7 \\
\hline & & $x_{2,6}$ & 0.15 & 5.7 & 5.2 & 5.0 & 4.8 \\
\hline & & $x_{2,10}$ & 0.10 & 8.4 & 7.7 & 7.5 & 8.5 \\
\hline & & $x_{2,14}$ & 0.15 & 8.5 & 7.5 & 8.4 & 7.8 \\
\hline & & $x_{2,15}$ & 0.10 & 8.3 & 7.4 & 7.3 & 7.8 \\
\hline \multirow{6}{*}{ Process indexes } & \multirow{6}{*}{0.35} & $x_{3,1}$ & 0.25 & 7.0 & 7.1 & 6.3 & 6.1 \\
\hline & & $x_{3,6}$ & 0.15 & 7.9 & 7.0 & 7.3 & 8.5 \\
\hline & & $x_{3,11}$ & 0.15 & 7.7 & 8.5 & 8.6 & 7.6 \\
\hline & & $x_{3,16}$ & 0.15 & 8.0 & 7.4 & 8.3 & 8.4 \\
\hline & & $x_{3,20}$ & 0.15 & 7.6 & 6.4 & 6.1 & 7.0 \\
\hline & & $x_{3,23}$ & 0.15 & 6.3 & 7.2 & 6.0 & 5.7 \\
\hline
\end{tabular}

Table 2. Low carbon level evaluation index systems of logistics enterprises

Step 4. Fuzzy comprehensive evaluation to T. Based on $U_{d}(d=1,2, \ldots, g)$, we can get the membership degree matrix of each enterprise to the overall target $R=\left(U_{1}^{\prime}, U_{2}^{\prime}, \ldots, U_{g}^{\prime}\right)^{\prime}$, and the corresponding membership degree vector $U=\left(u_{1}, u_{2}, \ldots, u_{m}\right)$.

Step 5. Selection. According to the principle of maximum membership degree, we sort each component of $U$ in descending order, then we get the corresponding priority sequence of each evaluation enterprises.

\section{Numerical Example}

There are four enterprises $E_{i}(i=1,2,3,4)$ scored by experts according to the simplified index system. The characteristic value of the indexes and corresponding weights of every company are showed in Table 2. Three first level indices contain 2, 8 and 6 second-level indices respectively.

Evaluate the low carbon development level of the 4 enterprises by using the above method, it is easy to obtain their membership degree to the strategy index

$$
U_{1}=\left(\begin{array}{llll}
1.0000 & 0.0772 & 0.000 & 0.0884
\end{array}\right) .
$$

The same can be obtained:

$$
\begin{aligned}
& U_{2}=\left(\begin{array}{llll}
0.9136 & 0.1259 & 0.3957 & 0.4783
\end{array}\right) . \\
& U_{3}=\left(\begin{array}{llll}
0.7317 & 0.6359 & 0.3297 & 0.3234
\end{array}\right) .
\end{aligned}
$$


The membership degree matrix to the total goals is:

$$
R=\left(\begin{array}{llll}
1.0000 & 0.0772 & 0.0000 & 0.0884 \\
0,9136 & 0.1259 & 0.3957 & 0.4783 \\
0.7317 & 0.6359 & 0.3297 & 0.3234
\end{array}\right) \quad h=\left(\begin{array}{l}
1.0000 \\
0,9136 \\
0.7317
\end{array}\right), b=\left(\begin{array}{l}
0.0000 \\
0,1259 \\
0.3234
\end{array}\right)
$$

Then we can obtain the membership degree vector of each enterprises:

$$
U=\left(\begin{array}{llll}
1.000 & 0.070 & 0.114 & 0.488
\end{array}\right)
$$

So the ranking of low carbon development level of 4 logistics enterprises is: $E_{1}>E_{4}>E_{3}>E_{2}$.

From the analysis and evaluation results, it is not difficult to see that enterprise $E_{1}$ ranks the first place for a higher score in the selected indexes; $E_{2}$ is superior to $E_{3}$ in the membership degree evaluation for the process indexes, but the overall evaluation of low carbon development level of $E_{2}$ is the worst, it is because of its low score of the key indexes in strategy indices and technical indices. Moreover, $E_{1}$ and $E_{4}$ is relatively close to each index in score. The reason for $E_{1}$ wins ultimately is that it is in the lead on the key indexes of high weighs such as Perfection degree of low carbon development strategy, Level of transportation route optimization, etc. It also helps enterprises to realize the sustainable development by identifying the key factors that affect the low carbon development level.

\section{Conclusion}

Based on the key component elements of low carbon logistics, this paper proposed a simple and efficient evaluation index system for low carbon development level of logistics enterprises in China. The simplified evaluation system resulted from the factor analysis method consists of 4 first-class indices and 20 second-class indexes. Then Validity judgment method and Reliability coefficient method were respectively used to evaluate the efficiency and reliability of the simplified index system. Finally we evaluated and compared the low carbon level of the logistics enterprises using the fuzzy evaluation method. Numerical examples illustrated the validity and efficiency of the index system. Establishing a low carbon logistics development evaluation index system can guide logistics enterprises to advance their low carbon production level and sustainable development.

\section{Acknowledgments}

First author partially supported by the Independent Innovation Foundation of Shandong University, IIFSDU (IFW12109), The key project of philosophy and social science plan of Jinan (2014). Shandong Province Natural Science Foundation (ZR2015GM012). 


\section{References}

Bi, K., Huang, P., \& Ye, H. (2015). Risk identification, evaluation and response of low-carbon technological innovation under the global value chain: A case of the Chinese manufacturing industry. Technological Forecasting and Social Change, 100, 238-248. http://dx.doi.org/10.1016/j.techfore.2015.07.005

Ding, Y. (2011). Development and thinking of low carbon in China. China Business \& Trade, 20, 120-121.

Fan, W. (2014). Research on low carbon logistics environmental impact evaluation model. LISS 2014. Springer Berlin Heidelberg. http://dx.doi.org/10.1007/978-3-662-43871-8_217

Feng, B. (2011). Study on the construction of low carbon economy evaluation in Hubei Province. China Population Resources and Environment, 21, 54-58.

Feng, S. (2010). Construction of enterprise technological innovation, ability evaluation index. Oriental Enterprise Culture, 2,193-194.

Geng, B., \& He, M. (2011). Low carbon logistics under low carbon economy. China Business \& Trade, $18,120-121$.

Gu, X., Chi, G., \& Cheng, H. (2010). The establishment of science and technology evaluation indicators system based on cluster-factor analysis. Studies in Science of Science, 28, 508-514.

He, X. (2007). Modern Statistics Analysis Method and Application. Beijing: Renmin University of China Press.

Hu, D., \& Ding S. (2010). Research on evaluation index system of low carbon economy. Science \& Technology Progress and Policy, 27, 160-164.

Li, X., \& Deng, L. (2010). Exploration on comprehensive evaluation of the city's low-carbon economy-Take municipalities as examples[J]. Exploration on the modern economy, 2, 82-85.

Li, Y., Xiong, Y., \& Zhang, L. (2011). The key factor evaluating system of low carbon logistics enterprises development based on ANP. Logistics Engineering and Management, 33, 23-25.

Luo, X., \& Xiao, X. (2011). Quantitative analysis and application of the enterprise's resource losses based on low-carbon development. China Population Resources and Environment, 21, $36-40$.

Ni, M., \& Xu, F. (2007). Study of enterprise information evaluation indicators and methods. Library and Information Service, 51, 75-79. 
Phillips, M., \& Dickie, J. (2014). Narratives of transition/non-transition towards low carbon futures within English rural communities. Journal of Rural Studies, 34, 79-95. http://dx.doi.org/10.1016/j.jrurstud.2014.01.002

Ren, Q., \& Wu, Y. (2011). Low-carbon Logistics Measures in Low-carbon era. Logistics Engineering and Management, 33, 11-13.

Shen, J., Xue, S., Zeng, M., Wang, Y., Wang, Y., Liu, X. et al. (2014). Low-carbon development strategies for the top five power generation groups during China's 12th Five-Year Plan period. Renewable and Sustainable Energy Reviews, 34, 350-360. http://dx.doi.org/10.1016/j.rser.2014.03.029

Tsai, M., \& Chang, S. (2015). Taiwan's 2050 low carbon development roadmap: An evaluation with the MARKAL model. Renewable and Sustainable Energy Reviews, 49, 178-191. http://dx.doi.org/10.1016/j.rser.2015.04.153

Wang, Z. (2012). Low carbon economy and the greening of logistics enterprises. China Business and Market, 26, 67-71.

$\mathrm{Wu}, \mathrm{N}$. (2011). Study of the third party reverse logistics suppliers evaluation index under low carbon concept. Logistics Research, 32, 44-45.

Xiao, S., Yin, G., Wang, Y., \& Shi, Y. (2005). Research on evaluating index \& method of enterprise informationization level. Computer Integrated Manufacturing Systems, 11, 1154-1162.

Xu, B., \& Bao, T. (2011). Quantitative and comprehensive evaluation of qualitative index in dam safety monitoring. Advances in Science and Technology of Water Resources, 31, 59-63.

Zhao, L., Sun, L., \& Liu, J. (2009). Regional manufacturing capacity for sustainable development evaluation system construction and application. Science and Technology Progress and Policy, 5, 5-54.

Zhuang, G., Pan, J., \& Zhu, S. (2011). The content of low-carbon economy and construction of comprehensive evaluation index system[J]. Dynamic Economics, 1, 132-136.

Journal of Industrial Engineering and Management, 2015 (www.jiem.org)

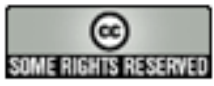

Article's contents are provided on an Attribution-Non Commercial 3.0 Creative commons license. Readers are allowed to copy, distribute and communicate article's contents, provided the author's and Journal of Industrial Engineering and Management's names are included. It must not be used for commercial purposes. To see the complete license contents, please visit http://creativecommons.org/licenses/by-nc/3.0/. 